\title{
Modeling of a hybrid energy storage system supplied by a photovoltaic source to feed a DC motor
}

\author{
M. A. Camara ${ }^{1}$, A. Djellad ${ }^{2}$, P. O. Logerais ${ }^{3,}$, O. Riou ${ }^{3}$, J. F. Durastanti ${ }^{3}$ \\ ${ }^{1}$ Université Gamal Abdel Nasser, Institut Polytechnique de Conakry (IPC), avenue des Princes, Conakry, Guinea \\ ${ }^{2}$ Université Badji Mokhtar, Faculté des sciences de l'ingéniorat, Laboratoire d'électrotechnique, BP 12, Annaba 2300, Algeria \\ ${ }^{3}$ Université Paris-Est, CERTES, IUT de Sénart, rue Georges Charpak, 77567 Lieusaint, France
}

\section{Email address:}

mohamedansoumane@yahoo.fr (M. A. Camara),djellad.abd@hotmail.fr (A. Djellad), pierre-olivier.logerais@u-pec.fr (P. O. Logerais), olivier.riou@u-pec.fr (O. Riou), durastanti@u-pec.fr (J. F. Durastanti)

\section{To cite this article:}

M. A. Camara, A. Djellad, P. O. Logerais, O. Riou, J. F. Durastanti. Modeling of A Hybrid Energy Storage System Supplied by a Photovoltaic Source to Feed a DC Motor. International Journal of Renewable and Sustainable Energy. Vol. 2, No. 6, 2013 , pp. $222-228$. doi: $10.11648 /$ j.jirse.20130206.16

\begin{abstract}
The storage of photovoltaic energy by associating batteries with ultracapacitors is investigated. A solar hybrid energy conversion system including photovoltaic module and a DC motor is modeled with a circuit-based approach. The different phases are simulated with a control on the voltage, current and state of charge. First, the duration of the storage of photovoltaic energy is acquired. Then, the current peaks supplied by ultracapacitors at DC motor start are depicted in the transient regime. The batteries are therefore less solicited at this instant and ensure steady-state feeding of the DC motor. The autonomy and implementation of the system in which ultracapacitors are integrated are discussed.
\end{abstract}

Keywords: Photovoltaic Energy, Ultracapacitor, Battery, DC Motor, Model

\section{Introduction}

Conversion systems with renewable energy sources require storage to supply electricity according to demand. Combination of storage means is necessary to charge and discharge with different time constants. Complementary to conventional batteries with slow dynamics, ultracapacitors deliver electrical power peaks which allow to smooth the power flow in case of intermittency of energy source or to overcome the initial inertia at the start of a motor [1]. Their discharge durations are indeed in the range of 1 to 10 seconds and very high number of cycles can be performed.

Manufacturers and research workers have been looking for increasing the capacitances and voltages of supercapacitors since the 1990s, namely with the need of the electric vehicle market $[2,3]$. The complementarity between power and energy by combining ultracapacitors with batteries is still being developed nowadays regarding vehicle applications [4,5]. Simulation results for urban vehicle highlights well that hybridization permits to improve the efficiency and the reliability of the source by reducing the maximum battery current and the number of cycles, by slowing down battery aging process and by extending time periods between maintenance (costly battery replacement operations) [6]. In hybrid railway electric vehicle, computing lookahead search lets to minimize energy losses to dispose of an optimal control of electrical energy amounts in the operations [7]. To improve energy efficiency of the railway system and utilize the surplus regenerative energy when braking, a DC railway power flow algorithm has been developed to determine the optimized feeder voltage control range for the charging-discharging of the ultracapacitor energy storage to maximize the improvement of energy efficiency and minimize the total storage capacity [8].

In solar applications, ultracapacitors charged by photovoltaic cells can be put to use in different cases: street lighting [9], harvesting wireless sensor [10], hybrid source [11]. Like in vehicle applications, the battery-ultracapacitor combination is interesting. Namely, it allows to compensate the fluctuating power from a photovoltaic source with use of a control loop [12]. Moreover, control with hysteretic loop enables to extend the battery lifetime by avoiding small charge/discharge cycles to keep the balance of instantaneous power and regulate the frequency of autonomous microgrid [13]. The battery-ultracapacitor combination has also proved to be a means to obtain pulsed load currents [14].

Besides, this association is worthy for autonomous motor in pumping or irrigation systems [15]. Ultracapacitors 
furnish high inrush current when starting the motor whereas the battery keeps the motor running in steady state. Ultracapacitors ensure the task of providing high discharge current which alleviates the battery voltage drop. High power variations considerably reduce the battery lifetime which have to be replaced every two years in off-grid photovoltaic systems [16,17]. Ultracapacitors have a long lifetime which can exceed 10 years and a few hundred thousand cycles [18].

Charge/discharge control of combined batteries and ultracapacitors is crucial to achieve optimal energy transfer and long lifetime of the storage system and related elements [19]. Management when batteries and supercapacitors are combined together to supply load demand has to be mastered to ensure balanced charging, avoid interaction between charging and discharging processes and adapt storage according to upstream source and load demand. At motor start, supercapacitors provide power peaks while battery has to reach steady-state and then maintain the motor and its nominal speed with constant discharge. The minimum current has to be drawn for the batteries in the transient phase. Two individual loops are therefore required to control both the batteries and the supercapacitors current and voltage. Moreover, the nonlinear behavior of capacitance of ultracapacitors has to be accounted for [20] as well as the ones of the photovoltaic source and the load [21].

In the present paper, a hybrid energy storage system (HESS) is modeled with charge/discharge controlling in the case of photovoltaic energy use. The stored energy is utilized to feed a DC motor. Fine electrical circuit modeling of the photovoltaic module, energy storage elements and DC motor is realized to take into account their nonlinear behaviors. The aim is to depict the evolution of physical characteristics of the HESS in three different phases: photovoltaic energy storage, DC motor start and its functioning. The implementation and the autonomy of the system are discussed.

\section{System Description and Modeling}

The schematic of the HESS in the energy conversion chain is given by figure 1 . The chain is composed of a photovoltaic module, a charge controller, a bank of ultracapacitors combined with a set of batteries (HESS) which when discharging feed a DC motor. Circuit-based modeling has been realized for each element of the chain because it is a good compromise between fine description and macroscopic approach.

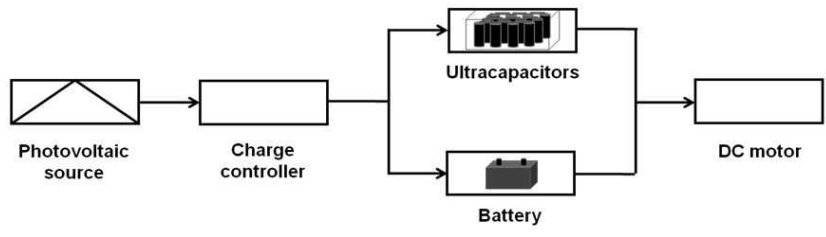

Figure 1. Energy conversion chain.
The photovoltaic current is determined with the classical equivalent electrical circuit in which an ideal current source (short-circuit current) is in parallel with one diode reproducing recombination and with one shunt (or parallel) resistor associated with a series resistor (see figure 2 ). The current $\mathrm{I}$ is related to the voltage $\mathrm{V}$ by:

$$
I=I_{p v}-I_{0}\left[\exp \left(\frac{V+R_{S} \cdot I}{V_{t} \cdot a}\right)-1\right]-\frac{V+R_{S} \cdot I}{R_{P}}
$$

where $I_{p v}$ is the current generated by the incident light (directly proportional to the solar irradiance $\mathrm{G}$ ); the second term corresponds to $I_{d}$, the Shockley diode equation, in which $I_{0}$ is the reverse saturation or leakage current of the diode, $\mathrm{V}_{\mathrm{t}}=\mathrm{N}_{\mathrm{s}} \mathrm{kT} / \mathrm{q}$ with $\mathrm{q}=1.60217646 \times 10^{-19} \mathrm{C}$ (the electron charge), $\mathrm{k}=1.3806503 \times 10^{-23} \mathrm{~J}_{\mathrm{K}} \mathrm{K}^{-1}$ (the Boltzmann constant) and $\mathrm{T}$ the temperature of the $\mathrm{p}-\mathrm{n}$ junction (in $\mathrm{K}$ ), and $\mathrm{a}$ is the diode ideality factor. In the case of $\mathrm{N}_{\mathrm{p}}$ groups of $\mathrm{N}_{\mathrm{s}}$ cells in series connected in parallel, the current obtained from (1) has to be multiplied by $\mathrm{N}_{\mathrm{p}}$. The open-circuit voltage/temperature coefficient $\mathrm{K}_{\mathrm{v}}$ and the short-circuit current/temperature coefficient $\mathrm{K}_{\mathrm{I}}$ are used to take into consideration the temperature influence [22]:

$$
\begin{aligned}
& I_{p v}=\left(I_{p v, n}+K_{I} \Delta T\right) \frac{G}{G_{n}} \\
& I_{0}=\frac{I_{s c, n}+K_{I} \cdot \Delta T}{\exp \left(\frac{V_{o c, n}+K_{V} \cdot \Delta T}{a \cdot V_{t}}\right)-1}
\end{aligned}
$$

where $\Delta \mathrm{T}=\mathrm{T}-\mathrm{T}_{\mathrm{n}}$ and nominal conditions are $\mathrm{T}_{\mathrm{n}}=25^{\circ} \mathrm{C}$ and $\mathrm{G}_{\mathrm{n}}=1000 \mathrm{~W} \cdot \mathrm{m}^{-2}$.

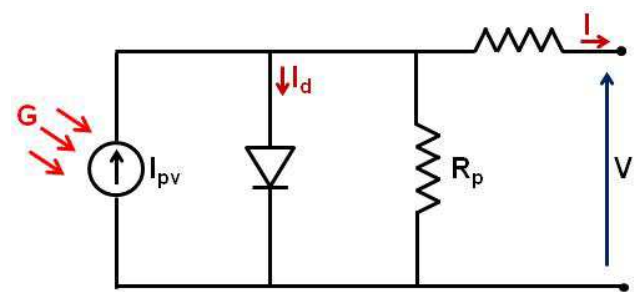

Figure 2. Equivalent electrical circuit of a photovoltaic module.

The ultracapacitors are modeled with a multibranch circuit, consisting of RC branches in parallel, as depicted in figure 3 [23]. RC cells with short time responses reproduce the transmission line behavior whereas longer time ones model redistribution and self-discharge. The transmission line has an access resistor and its capacitance $\mathrm{C}$ is voltage dependent. The capacitances $\mathrm{C}_{2}$ and $\mathrm{C}_{3}$, for redistribution and self-discharge, also depend on the voltage.

The management of charge/discharge of the ultracapacitors and the batteries regarding upstream photovoltaic source and downstream DC motor is ensured by a charge controller. The ultracapacitors and the batteries are successively charged and discharged to feed the DC motor. Two diodes prevent energy exchange between the 
batteries and the ultracapacitors.

The entire system has been implemented in the SimPowerSystems environment of Matlab/Simulink software. The realized block diagram representation is shown in figure 4 . The equivalent electrical circuit of the photovoltaic cells of figure 2 is included in the sub system "PV module". The multibranch circuit of figure 3 is placed in the sub system "ultracapacitors". Nested blocks were created to consider the non linearity of capacitances of supercapacitor. Hence, another sub model was built up within the capacitance properties (figure 5) [24]. Fifteen RC branches are considered ( $\mathrm{n}=15$ in figure 3 ) to have sufficient accuracy of the transmission line $[23,25]$. This multibranch model has been validated with photovoltaic source in a previous study [26]. The battery storage is modeled with the available block in SimPowerSystems. Timers, logical commands, relays and switches are combined to simulate the functionalities of the charge controller (figure 4).

The data of the model are provided in table 1 . The number of storage units is chosen so as to match the nominal voltage and current of the DC motor: $\mathrm{V}_{\mathrm{m}, \mathrm{n}}=240 \mathrm{~V}$ and $I_{m, n}=16.2$ A. So, a pack of five lead-acid batteries in series each of nominal voltage $\mathrm{V}_{\mathrm{b}, \mathrm{n}}=48 \mathrm{~V}$ and rated capacity of $\mathrm{C}_{\mathrm{b}}=16.2$ A.h, and a bank composed of 96 ultracapacitors in series of type Maxwell PC7223 each of nominal voltage $\mathrm{V}_{\mathrm{uc}, \mathrm{n}}=2.5 \mathrm{~V}$ constitute the HESS. A module of ten photovoltaic arrays in series type Kyocera KC200GT is taken $\left(\mathrm{V}_{\mathrm{oc}, \mathrm{n}}=32.9 \mathrm{~V}\right.$ and $\left.\mathrm{I}_{\mathrm{sc}, \mathrm{n}}=8.21 \mathrm{~A}\right)$. The characteristics of the multibranch circuit were obtained under constant current partial charges and discharge [23]. Expressions of nonlinear capacitances $\mathrm{C}, \mathrm{C}_{2}$ and $\mathrm{C}_{3}$ are given in table 1. Other nominal characteristics of the DC motor are [27]: power $\mathrm{Pe}_{\mathrm{n}}=3731 \mathrm{~W}=5.0 \mathrm{HP}$, rotation speed $\omega_{\mathrm{n}}=1220 \mathrm{rpm}$ and torque $\mathrm{T}_{\mathrm{e}, \mathrm{n}}=29.2$ N.m. The torque $T_{e}$ is assumed proportional to rotation speed $\omega$. A three-step starter $\left(\mathrm{t}_{0}+2.8 \mathrm{~s} / 4.8 \mathrm{~s} / 6.8 \mathrm{~s}\right)$ with total resistance $6.04 \Omega$ is used to protect the engine by keeping the inrush current inferior to $2 \mathrm{I}_{\mathrm{m}, \mathrm{n}}=36.4 \mathrm{~A}$. Ultracapacitors discharge at $\mathrm{t}_{0}$ and ensure the power demand at motor start to reach nominal regime.

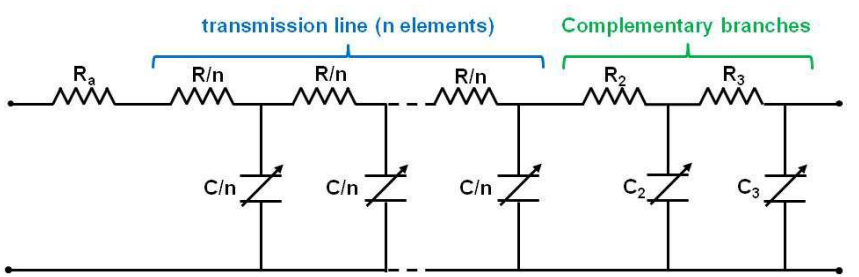

Figure 3. Multibranch circuit of an ultracapacitor.

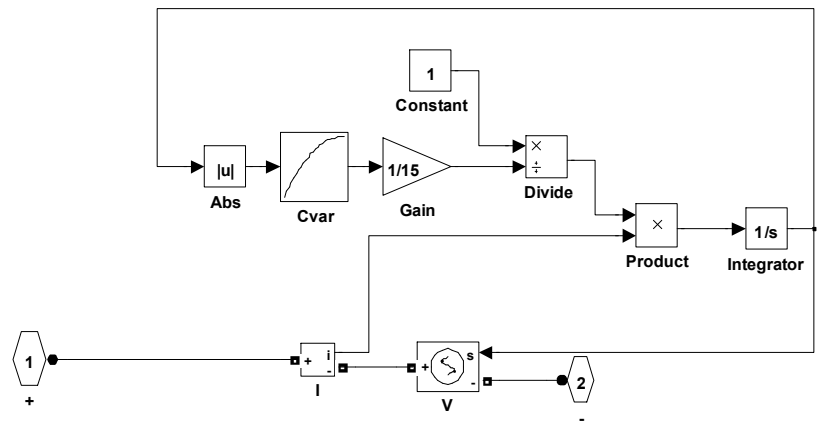

Figure 5. Simulink sub block for the voltage dependency of capacitance in the multibranch model of an ultracapacitor.

\section{Table 1. Model data.}

$$
\begin{aligned}
& \text { PV module: Kyocera KC200GT } \\
& \mathrm{V}_{\mathrm{oc}, \mathrm{n}}=32.9 \mathrm{~V} ; \mathrm{I}_{\mathrm{sc}, \mathrm{n}}=8.21 \mathrm{~A} \\
& \mathrm{R}_{\mathrm{S}}=0.221 \Omega ; \mathrm{R}_{\mathrm{p}}=415.4 \Omega ; \mathrm{a}=1.3 \\
& \mathrm{~N}_{\mathrm{s}}=54 \\
& \mathrm{~T}_{\mathrm{n}}=25+273.15 \mathrm{~K} ; \mathrm{G}_{\mathrm{n}}=1000 \mathrm{~W} \cdot \mathrm{m}^{-2} \\
& \mathrm{~K}_{\mathrm{I}}=0.0032 \mathrm{~A} \cdot \mathrm{K}^{-1} ; \mathrm{K}_{\mathrm{V}}=-0.1230 \mathrm{~V} \cdot \mathrm{K}^{-1}
\end{aligned}
$$

\section{Ultracapacitor: Maxwell PC7223}

$$
\begin{aligned}
& \mathrm{V}_{\mathrm{uc}, \mathrm{n}}=2.5 \mathrm{~V} ; \mathrm{R}_{\mathrm{uc}}=0.85 \mathrm{~m} \Omega ; \mathrm{C}_{\mathrm{uc}}=2700 \mathrm{~F} \\
& \mathrm{R}_{\mathrm{a}}=0.5 \mathrm{~m} \Omega \\
& \mathrm{R}=1,1 \mathrm{~m} \Omega ; \mathrm{C}(\mathrm{V})=-196.4 \mathrm{~V}^{2}+925.4 \mathrm{~V}+1976.8 \\
& \mathrm{R}_{2}=100 \mathrm{~m} \Omega ; \mathrm{C}_{2}(\mathrm{~V})=-8.9286 \mathrm{~V}^{2}+40.2643 \mathrm{~V}+88.9643 \\
& \mathrm{R}_{3}=1 \Omega ; \mathrm{C}_{3}(\mathrm{~V})=-1.8571 \mathrm{~V}^{2}+12.4714 \mathrm{~V}+31
\end{aligned}
$$

Lead acid battery

$$
\begin{aligned}
& \mathrm{V}_{\mathrm{b}, \mathrm{n}}=48 \mathrm{~V} ; \mathrm{C}_{\mathrm{b}, \mathrm{n}}=16.2 \mathrm{~A} \cdot \mathrm{h} \\
& \text { DC motor } \\
& \mathrm{R}_{\mathrm{ar}}=0.6 \Omega ; \mathrm{L}_{\mathrm{ar}}=0.012 \mathrm{H} \\
& \mathrm{R}_{\mathrm{f}}=240 \Omega ; \mathrm{L}_{\mathrm{f}}=120 \mathrm{H} ; \mathrm{L}_{\mathrm{af}}=1.8 \mathrm{H} \\
& \mathrm{J}=1 \mathrm{~kg} \cdot \mathrm{m}^{2} \\
& \mathrm{~B}_{\mathrm{m}}=0 \mathrm{~N} \cdot \mathrm{m} . \mathrm{s} ; \mathrm{T}_{\mathrm{f}}=0 \mathrm{~N} \cdot \mathrm{m} \\
& \mathrm{T}_{\mathrm{e}}=0.2287 \omega
\end{aligned}
$$




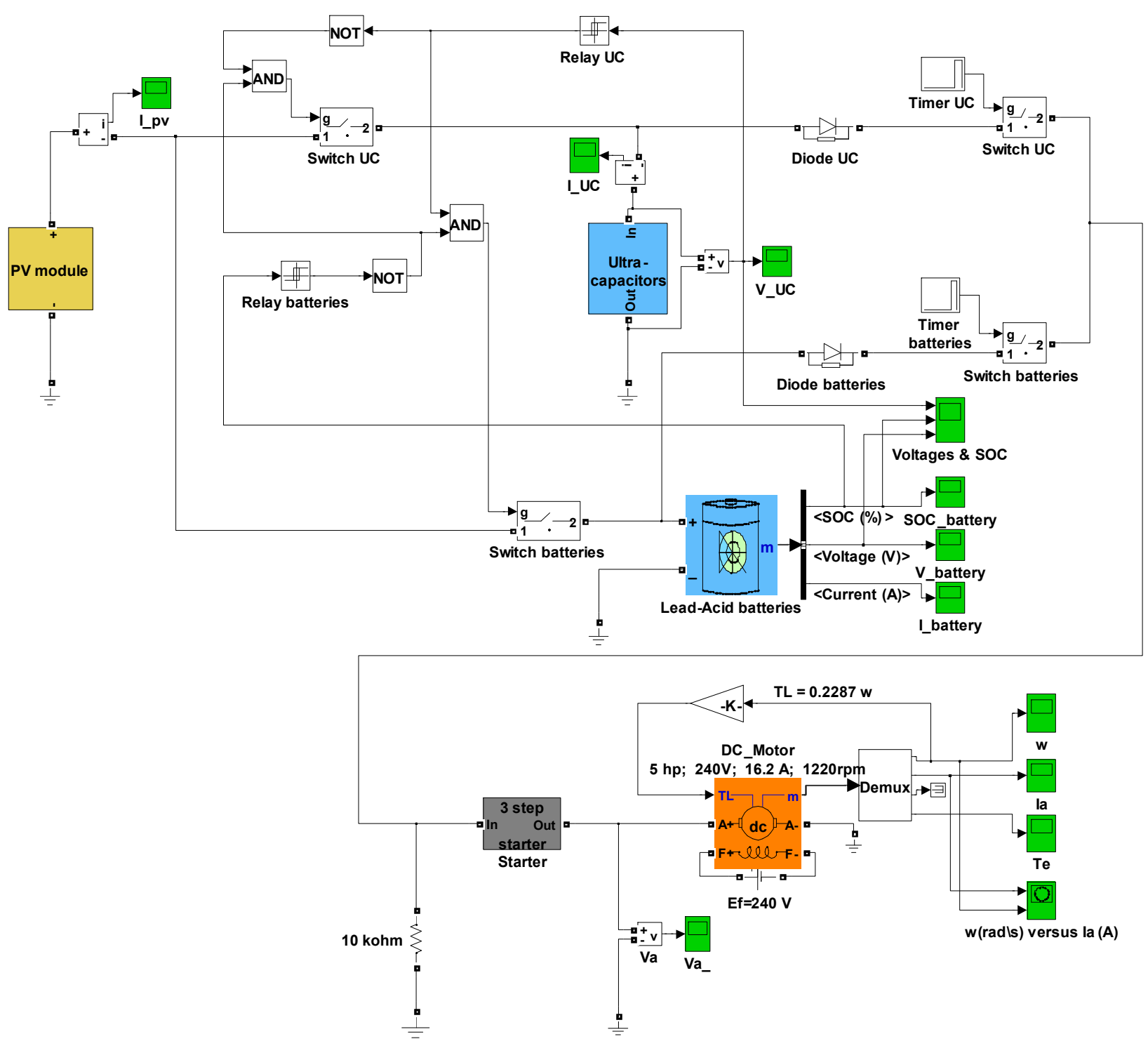

Figure 4. Simulink block diagram of the hybrid energy conversion system supplied by photovoltaic source.

\section{Results and Discussion}

Simulations were performed for an overall duration of $3 \mathrm{~h} 30$ (12500s). The solar irradiance onto the photovoltaic module is taken at $1000 \mathrm{~W} \cdot \mathrm{m}^{-2}$ and cell temperature at $25^{\circ} \mathrm{C}$ (standard test conditions, STC). Simulations were also carried out with battery alone for charge/discharge for comparison. The voltage of the bank of ultracapacitors, the state of charge (SOC) of the batteries, the rotation speed, the current and the torque of the DC motor are monitored. The evolutions acquired are commented in the present section.

Once the bank of ultracapacitors is charged, in other words a $240 \mathrm{~V}$ voltage is reached, the battery charge takes place (figure 6). The ultracapacitors bank charges in $887 \mathrm{~s}$ (15 minutes) and the pack of batteries in $9164 \mathrm{~s}(2 \mathrm{~h} 30)$. The voltage of the batteries increases during charge state with a first-order shape evolution as described in [28] and its SOC increases in a linear manner.

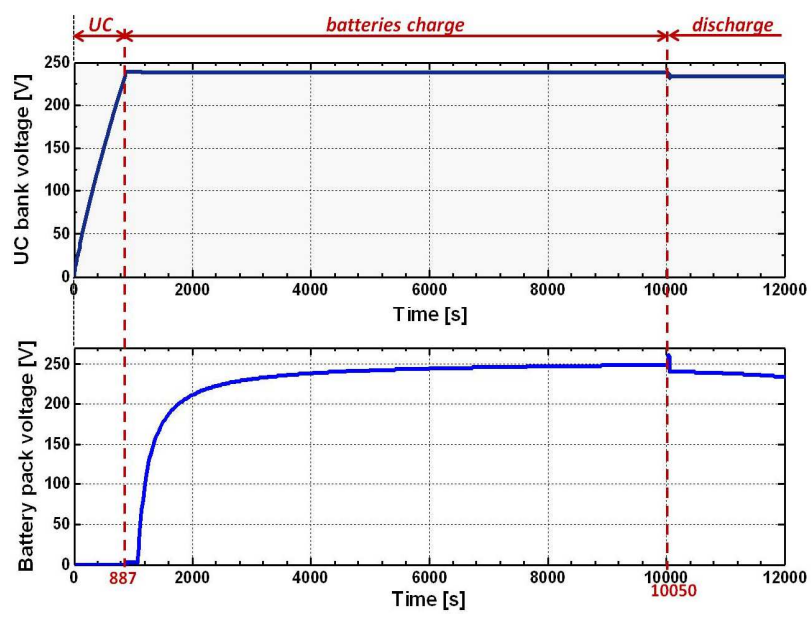

Figure 6. Successive charge of the ultracapacitors and the batteries until their discharge to feed the DC motor.

Figure 7 provides the evolution of the current and the rotation speed of the DC motor at its start. The first four 
current peaks are solely furnished by the ultracapacitors after $\mathrm{t}_{0}=10050 \mathrm{~s}$. The fifth current peak at $\mathrm{t}=10059 \mathrm{~s}$ appears when the batteries begin to discharge. The amplitudes of the peaks are inferior to $35.3 \mathrm{~A}$. This value of twice the nominal current is indeed high as it is advisable not to go beyond $1.5 \mathrm{I}_{\mathrm{m}, \mathrm{n}}$ but the durations are small. If we simulate the system without starter, the DC motor requires a peak of 300 A to overcome the initial inertia. This intensity would deteriorate the motor by namely provoking overheating of the inductor. The rotation speed reaches its nominal value of $1220 \mathrm{rpm}$ after the fourth level. Thereafter, the batteries begin discharging at a voltage of $240 \mathrm{~V}$. Another current peak appears with an additional step because the ultracapacitors are partially discharged and their voltage has decreased from $240 \mathrm{~V}$ to $234 \mathrm{~V}$. The motor functions at its nominal speed with battery supplying. An overshoot of the rotation speed which goes up to $1240 \mathrm{rpm}$ can be noticed when the batteries begin to discharge. A management which reduces the peak of the battery and gives a more progressive speed evolution at this moment would be interesting to search. Nevertheless, the perfect control strategy for a HESS is a difficult task [19]. If the batteries were alone, they would have to hand out the first four peaks. The frequency of solicitations is reduced, thus the stress is diminished [29].

The batteries feed the motor until the SOC gets down to $40 \%$ (figure 8). This threshold of discharge is not too deep and allows longer lifetime for the batteries [21]. The engine is fed for $2350 \mathrm{~s}$ (40 minutes). This autonomy duration of the motor is in the same magnitude than the one found in the study of Glavin and Hurley [15]. The batteries deliver slightly longer current in steady functioning of the motor. Indeed, in case of lone batteries, the operating duration is reduced to $2290 \mathrm{~s}$ because batteries lose energy to supply the four current peaks at start. In our case, one charge/discharge cycle is performed. During this cycle, after motor start, the ultracapacitors have a voltage of $230 \mathrm{~V}$. At the end of this cycle, the batteries are charged by $40 \%$. Thus, the next cycle will be shorter and the energy stored in ultracapacitors must be harnessed.

The HESS would be worth implementing in the middle of a day when irradiance is maximum. The discharge of the batteries would be more interesting if realized the next morning because immediate recharge is advisable to limit the stress of batteries [29]. Maintaining lead-acid batteries with a SOC of $100 \%$ may also remove sulfation from the lead plates [30]. However, between end storage and beginning of discharge, self-discharge would occur for ultracapacitors [21].

This work is a first stage in dealing with a complete autonomy context. The model could be utilized to design a pumping system or an irrigation one [15,31]. For example pumped water in the morning could be stored in a tank to satisfy the demand during the day namely the peak consumption in the morning. Cost study and rentability of the integration of ultracapacitors should be realized because the sudden solicitations which deteriorate the batteries are alleviated. The risk of breakdown of the batteries is then low and less frequent replacements are necessary. Even though at first thought, supercapacitors appear expensive, their prices have been running down for the last ten years [11]. Long-term performance simulations accompanied with global cost and rentability could be performed with the present model.
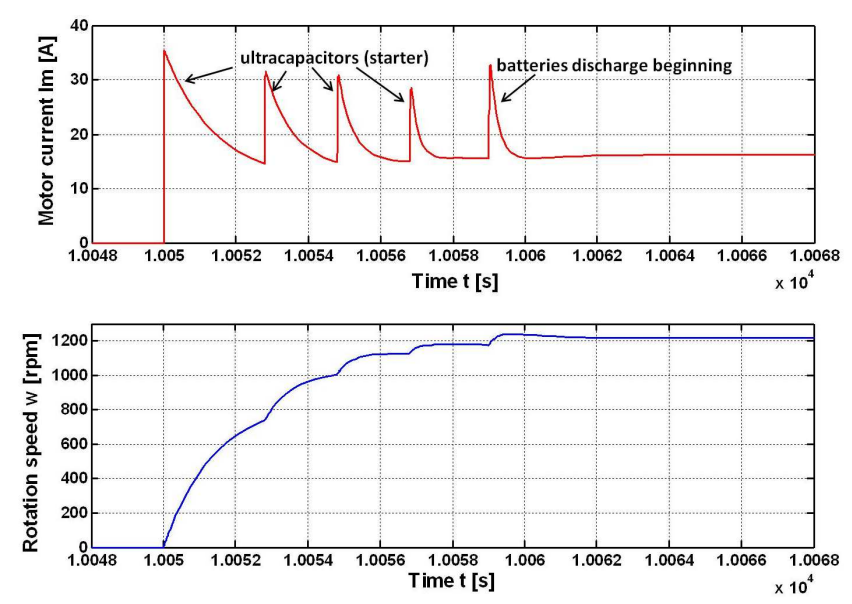

Figure 7. Current and rotation speed of the DC motor at start
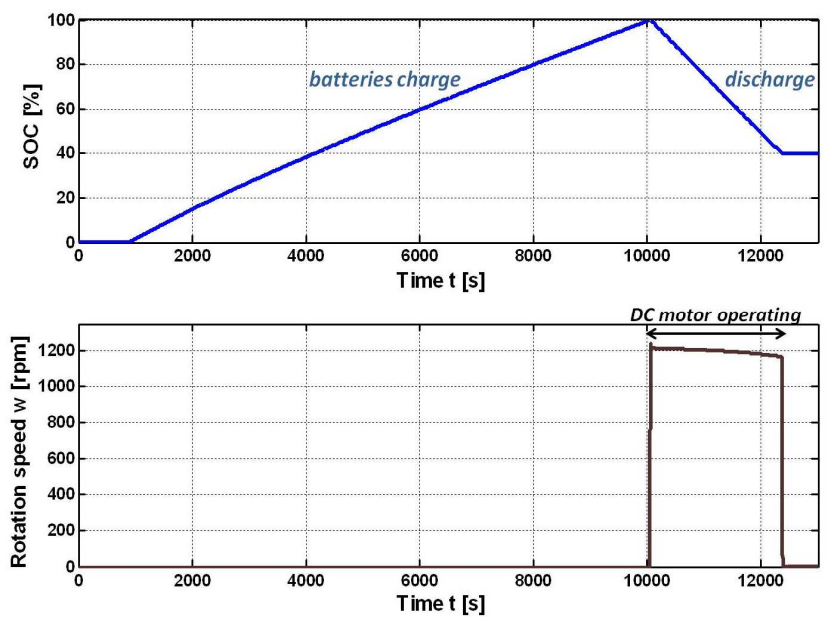

Figure 8. State of charge of the batteries and autonomy of the DC motor

\section{Conclusion}

A battery/supercapacitor management is modeled in the present study to address the charge and discharge issues in the case of a photovoltaic source and DC motor. The results clearly put into light the interest of integrating ultracapacitors in an autonomous solar energy conversion system. The power peak necessary at the engine start is supplied by ultracapacitors which allow to reduce electrical solicitations on polluting batteries and hence lengthen their lifetime. However, ultracapacitors are still expensive but their prices keep slumping and their projected cost in huge production is favorable. Furthermore, for photovoltaic standalone applications, the model established in this paper will enable to link weather conditions to hybrid battery/ultracapacitors energy storage and to dimension the 
"best fit" of ultracapacitors in a photovoltaic unit for an engine application.

\section{Acknowledgements}

The authors wish to thank Mrs. Wilhelmina Logerais for her help with English.

\section{Nomenclature}

a diode ideality factor

$\mathrm{B}_{\mathrm{m}} \quad$ viscous friction coefficient (N.m.s)

$\mathrm{C}$ transmission line capacitance $(\mathrm{F})$

$\mathrm{C}_{2}$ first complementary branch capacitance $(\mathrm{F})$

$\mathrm{C}_{3}$ second complementary branch capacitance $(\mathrm{F})$

$\mathrm{C}_{\mathrm{b}}$ rated capacity (A.h)

$\mathrm{G}$ solar global irradiance $\left(\mathrm{W} . \mathrm{m}^{-2}\right)$

I current intensity (A)

$\mathrm{I}_{0} \quad$ diode saturation current (A)

$\mathrm{I}_{\mathrm{d}} \quad$ diode current (A)

$\mathrm{I}_{\mathrm{pv}}$ photocurrent (A)

$\mathrm{I}_{\mathrm{sc}} \quad$ short-circuit current (A)

$\mathrm{J}$ total inertia $\left(\mathrm{kg} \cdot \mathrm{m}^{2}\right)$

$\mathrm{K}_{\mathrm{I}}$ short-circuit current/temperature coefficient (A.K $\left.\mathrm{K}^{-1}\right)$

$\mathrm{K}_{\mathrm{V}}$ open-circuit voltage/temperature coefficient $\left(\mathrm{V} . \mathrm{K}^{-1}\right)$

$\mathrm{L}_{\mathrm{af}}$ field-armature mutual inductance $(\mathrm{H})$

$\mathrm{L}_{\text {ar }}$ armature inductance $(\mathrm{H})$

$\mathrm{L}_{\mathrm{f}}$ field inductance $(\mathrm{H})$

$\mathrm{N}_{\mathrm{p}}$ number of cell groups in parallel

$\mathrm{N}_{\mathrm{s}}$ number of solar cells in series

Pe power $(\mathrm{W})$

$\mathrm{R}$ transmission line resistance $(\Omega)$

$\mathrm{R}_{2}$ first complementary branch resistance $(\Omega)$

$\mathrm{R}_{3} \quad$ second complementary branch resistance $(\Omega)$

$\mathrm{R}_{\mathrm{a}} \quad$ access resistance $(\Omega)$

$\mathrm{R}_{\mathrm{ar}}$ armature resistance $(\Omega)$

$\mathrm{R}_{\mathrm{f}} \quad$ field resistance $(\Omega)$

$\mathrm{R}_{\mathrm{p}} \quad$ parallel resistance $(\Omega)$

$\mathrm{R}_{\mathrm{s}} \quad$ series resistance $(\Omega)$

$\mathrm{T}$ time (s)

$\mathrm{T}$ junction temperature $(\mathrm{K})$

$\mathrm{T}_{\mathrm{e}}$ torque (N.m)

$\mathrm{T}_{\mathrm{f}} \quad$ Coulomb friction torque (N.m)

$\mathrm{V}$ voltage (V)

$\mathrm{V}_{\text {oc }}$ open-circuit voltage $(\mathrm{V})$

$\mathrm{V}_{\mathrm{t}}$ thermal voltage $(\mathrm{V})$

Greek symbol

$\omega$ rotation speed (rpm)

Indexes

b battery

m motor

$\mathrm{n}$ nominal

uc ultracapacitor

Constants

$\mathrm{k}=1.3806503 \times 10-23 \mathrm{~J} . \mathrm{K}^{-1}$ Boltzmann constant $\mathrm{q}=1.60217646 \times 10^{-19} \mathrm{C}$ electron charge

\section{References}

[1] A. Luque, S. Hegedus, Handbook of photovoltaic science and engineering, John Wiley and Sons Ltd., Chichester, 2003.

[2] A. Burke, M. Miller, Testing of electrochemical capacitors: capacitance, resistance, energy density and power capability, Electrochimica Acta, vol. 55, pp. 7538-7548, 2010.

[3] M. Mellincovsky, A. Kuperman, C. Lerman, I. Aharon, N. Reichbach, G. Geula, R. Nakash, Performance assessment of a power loaded supercapacitor based on manufacturer data, Energy Conversion and Management, vol. 76, pp. 137-144, 2013.

[4] M.Y. Ayad, M. Becherif, A. Henni, Vehicle hybridization with fuel cell, ultracapacitors and batteries, Renewable Energy, vol. 36, pp. 2627-2634, 2011.

[5] J.N. Marie-Françoise, H. Gualous, R. Outbib, A. Berthon, $42 \mathrm{~V}$ Power Net with ultracapacitor and battery for automotive applications, Journal of Power Sources, vol. 143, pp. 275-283, 2005.

[6] M. Michalczuk, L. M. Grzesiak, B. Ufnalski, A lithium battery and ultracapacitor hybrid energy source for an urban electric vehicle, Przegląd Elektrotechniczny (Electrical Review), vol. 88(4b), pp.158-162, 2012.

[7] R. Li, A. Pottharst, K. Witting, O. Znamenshchykov, J. Böcker, N. Fröhleke, R. Feldmann, M. Dellnitz, Design and Implementation of a Hybrid Energy Supply System for Railway Vehicles, Proc. APEC 2005, IEEE Applied Power Electronics Conference, 2005, Austin, Texas.

[8] H. Lee, J. Song, H. Lee, C. Lee, G. Jang, G. Kim, Capacity optimization of the ultracapacitor energy storages on DC railway system using a railway power flow algorithm, International Journal of Innovative Computing Information and Control, vol. 7(5B), pp. 2739-2753, 2011.

[9] R. Kötz, M. Carlen, Principles and applications of electrochemical capacitors, Electrochimica Acta, vol. 45, pp. 2483-2498, 2000.

[10] C. Renner, J. Jessen, V. Turau, Lifetime Prediction for Ultracapacitor-powered Wireless Sensor Nodes, Proceedings of the 8th GI/ITG KuVS Fachgespräch "Drahtlose Sensornetze" (FGSN'09), August 2009, pp. 55-58, Hamburg, Germany.

[11] A. Andreotti, F. Mottola, M. Pagano, G. Velotto, Design of ultracapacitor based filter for isolated PV source feeding pulsing load, Electric Power Systems Research, vol. 78, pp. 1038-1046, 2008.

[12] Z. Guoju, T. Xisheng, Q. Zhiping, Research on Battery Supercapacitor Hybrid Storage and its application in MicroGrid, Power and Energy Engineering Conference (APPEEC), 2010 Asia-Pacific, pp. 1-4, 28-31 March 2010.

[13] H. Jia, Y. Mu, Y. Qi, A statistical model to determine the capacity of battery-ultracapacitor hybrid energy storage system in autonomous microgrid, Electrical Power and Energy Systems, vol. 54, pp. 516-524, 2014.

[14] A. Kuperman, I. Aharon, Battery-ultracapacitor hybrids for pulsed current loads: a review, Renewable Sustainable Energy Review, vol. 15, pp. 981-992, 2011. 
[15] M.E. Glavin, W.G. Hurley, Optimisation of a photovoltaic battery ultracapacitor hybrid energy storage system, Solar Energy, vol. 86, pp. 3009-3020, 2012.

[16] A.M. Van Voorden, L.M.R. Elizondo, G.C. Paap, J. Verboomen, L. Van Der Sluis, The application of ultracapacitors to relieve battery storage systems in autonomous renewable energy systems, IEEE Lausanne Power Tech. 23, pp. 479-484, 2007.

[17] B.D. Vick, B.A. Neal, Analysis of off-grid hybrid wind turbine/solar PV water pumping systems, Solar Energy, vol. 86, pp. 1197-1207, 2012.

[18] A. Kusko, J. DeDad, Stored energy - Short-term and long-term energy storage methods, Industry Applications Magazine, IEEE, vol. 13(4), pp. 66-72, 2007.

[19] X. Tan, Q. Li, H. Wang, Advances and trends of energy storage technology in Microgrid, Electrical Power and Energy Systems, vol. 44, pp. 179-191, 2013.

[20] Y. Kim, N. Chang, Y. Wang, M. Pedram, Maximum Power Transfer Tracking for a Photovoltaic-Supercapacitor Energy System, Low-Power Electronics and Design (ISLPED), 2010 ACM/IEEE International Symposium, 18-20 August, Austin, USA, pp. 307-312, 2010.

[21] B. Multon, J. Aubry, P. Haessig, H. Ben Ahmed, Systèmes de stockage d'énergie électrique, Techniques de l'Ingénieur, 2013.

[22] M.G. Villalva, J.R. Gazoli, E. Ruppert F., Modeling and circuit-based simulation of photovoltaic arrays, Brazilian Journal of Power Electronics, vol. 14(1), pp. 35-45, 2009.

[23] F. Belhachemi, Modélisation et caractérisation des supercondensateurs à couche double électrique utilisés en électronique de puissance, $\mathrm{PhD}$ thesis, Nancy, 2001.
[24] M.A. Camara, Modélisation du stockage de l'énergie photovoltaïque par supercondensateurs, $\mathrm{PhD}$ thesis, Université Paris-Est, 2011.

[25] N. Rizoug, Modélisation électrique et énergétique des supercondensateurs et méthodes de caractérisation: application au cyclage d'un module de supercondensateurs basse tension en grande puissance, $\mathrm{PhD}$ thesis, Université de Lille, 2006.

[26] P.O. Logerais, O. Riou, M. A. Camara, J.F. Durastanti, Study of Photovoltaic Energy Storage by Supercapacitors through Both Experimental and Modelling Approaches, Journal of Solar Energy, vol. 2013, Article ID 659014, 9 pages, 2013.

[27] P.C. Krause, O. Wasynczuk, S.D. Sudhoff, S. Pekarek, Analysis of Electric Machinery, Wiley, 2013.

[28] Y. Hu, S. Yurkovich, Y. Guezennec, R. Bornatico, Model-Based Calibration for Battery Characterization in HEV Applications, 2008 American Control Conference, Westin Seattle Hotel, Seattle, Washington, USA, June 11-13, 2008 .

[29] D.U. Sauer, H. Wenzl, Comparison of different approaches for lifetime prediction of electrochemical systems-Using lead-acid batteries as example, Journal of Power Sources, vol. 176, pp. 534-546, 2008.

[30] A. W. Stienecker, T. Stuart, C. Ashtiani, An ultracapacitor circuit for reducing sulfation in lead acid batteries for Mild Hybrid Electric Vehicles, Journal of Power Sources, vol. 156, pp. 755-762, 2006.

[31] M.S.Y. Ebaid, H. Qandil, M. Hammad, A unified approach for designing a photovoltaic solar system for the underground water pumping well-34 at Disi aquifer, Energy Conversion and Management, vol. 75, pp. 780-795, 2013. 